\title{
Peripheral Nerve Injuries and Transplantation of Olfactory Ensheathing Cells for Axonal Regeneration and Remyelination: Fact or Fiction?
}

\section{Christine Radtke ${ }^{1,2,3, *}$ and Jeffery D. Kocsis ${ }^{2,3}$}

1 Department of Plastic, Hand- and Reconstructive Surgery, Hannover Medical School, 30625 Hannover, Germany

2 Department of Neurology and Center for Neuroscience and Regeneration Research, Yale University School of Medicine, New Haven, CT 06510, USA; E-Mail: jeffery.kocsis@yale.edu

3 Rehabilitation Research Center, Veterans Affairs Connecticut Healthcare System, West Haven, CT 06516, USA

* Author to whom correspondence should be addressed; E-Mail: radtke.christine@mh-hannover.de; Tel.: +49-511-532-8864; Fax: +49-511-532-8890.

Received: 2 August 2012; in revised form: 7 September 2012 / Accepted: 7 September 2012 /

Published: 10 October 2012

\begin{abstract}
Successful nerve regeneration after nerve trauma is not only important for the restoration of motor and sensory functions, but also to reduce the potential for abnormal sensory impulse generation that can occur following neuroma formation. Satisfying functional results after severe lesions are difficult to achieve and the development of interventional methods to achieve optimal functional recovery after peripheral nerve injury is of increasing clinical interest. Olfactory ensheathing cells (OECs) have been used to improve axonal regeneration and functional outcome in a number of studies in spinal cord injury models. The rationale is that the OECs may provide trophic support and a permissive environment for axonal regeneration. The experimental transplantation of OECs to support and enhance peripheral nerve regeneration is much more limited. This chapter reviews studies using OECs as an experimental cell therapy to improve peripheral nerve regeneration.
\end{abstract}

Keywords: peripheral nerve injury; cell transplantation; olfactory ensheathing cells; axonal regeneration; remyelination; nerve defect; nerve conduit 
Abbreviations: CHS, collagen-heparan sulphate; CNS, central nervous system; DREZ/DH, dorsal root entry zone/dorsal horn; ECM, extracellular matrix; EMG, electromyography; GFP, green fluorescent protein; CMAP, compound muscle action potential; Nav, voltage-gated TTX-sensitive sodium channels; Nav1.6, voltage gated sodium channel subtype 1.6; NGF, nerve growth factor; NCV, nerve conduction velocity; nerve growth factor; OB, olfactory bulb; OECs, olfactory ensheathing cells; OM, olfactory mucosa; PDLLA, poly D, L-lactic acid; PGA, polymer polyglycolic acid; PHB, poly-3-hydroxybutyrate; PLGL, poly [LA-co-(Glc-alt-Lys)]; PLLA, poly L-lactic acid; p75NGFR, p75 nerve growth factor receptor; PNS, peripheral nervous system; SFI, sciatic functional index; SpC, spinal cord.

\section{Introduction}

Peripheral nerve injury results in functional deficits of peripheral targets (e.g., muscle and sensory organs) which are innervated by the injured nerve [1]. Axonal regeneration is far more successful in peripheral nerve than in the central nervous system (CNS) because inhibitory myelin proteins are less prominent in the peripheral nervous system (PNS) and Schwann cells in the distal nerve segment mobilize and establish a permissive environment for axonal regeneration. While peripheral nerve regeneration is more successful than CNS axonal regeneration, it is often incomplete; the development of interventional approaches to enhance peripheral nerve regeneration such as an adjunct cell therapy is a clinically important objective. One reason for the success of PNS regeneration is that Schwann cells are an important endogenous element in peripheral nerve regeneration and remyelination. They provide neurotrophic support and axon guidance channels for axonal regeneration and will myelinate the regenerated axons to allow rapid impulse conduction. While endogenous Schwann cells can perform these functions, additional transplantation of glia cells, such as olfactory ensheathing cells into injured nerves, may help facilitate the repair process. This may be particularly important when there is a temporal delay in repair, because the endogenous Schwann cells may atrophy and no longer appropriately signal the axon for growth thus providing less trophic support such as nerve growth factor production.

Extensive experimental OEC transplantation has been employed as a strategy to repair the injured spinal cord [2,3] and demyelinated lesions [4-7]. Furthermore, clinical studies evaluating OEC transplantation for spinal cord injury are ongoing [8-11]. However, the number of OEC studies for peripheral nerve injury is much more limited (for overview see Table 1).

OECs have been studied in the context of enhancing repair of peripheral nerve by direct transplantation in different peripheral nerve lesion models for enhancement of axonal nerve regeneration by providing a scaffold for the regenerating axons as well as trophic factors and directional cues [12]. OECs are known to provide trophic factors conducive to axonal regeneration and survival. They may promote endogenous Schwann cell mobilization possibly by a trophic influence [13,14] and can form cellular bridges in CNS white matter through which axons can regenerate $[7,15]$. The CNS is less permissive for axonal regeneration and sprouting than peripheral nerve. Furthermore, the introduction of OECs into the injured CNS leads a more permissive environment with reduced myelin inhibitory molecules resulting in enhanced regeneration. 
Table 1. Summary of olfactory ensheathing cell (OEC) transplantation studies into peripheral nerve injury models.

\begin{tabular}{|c|c|c|c|c|c|}
\hline Nerve lesion model & OEC condition & OEC application & Outcome & Limits & Reference \\
\hline $\begin{array}{l}\text { Sciatic nerve crush } \\
\text { lesion (rat) }\end{array}$ & $\begin{array}{l}\text { GFP-OECs } \\
\text { purified } \\
30,000 \text { cells } / \mu \mathrm{L} \\
\text { and } 10 \mu \mathrm{L} \text { used }\end{array}$ & $\begin{array}{l}\text { OEC injection } \\
\text { proximal and distal } \\
\text { to lesion }\end{array}$ & $\begin{array}{l}\text { myelin formation and } \\
\text { axonal regeneration high } \\
\text { density of } \mathrm{Na}(\mathrm{v}) 1.6 \\
\text { newly formed nodes } \\
\text { of Ranvier }\end{array}$ & $\begin{array}{l}\text { no functional testing } \\
\text { performed }\end{array}$ & $\begin{array}{l}\text { Dombrowski } \\
\text { et al., } 2006 \\
{[16]}\end{array}$ \\
\hline $\begin{array}{l}\text { Sciatic nerve } \\
\text { transection and } \\
\text { silicone } \\
\text { entubulation (rat) }\end{array}$ & OB OECs & $\begin{array}{l}\text { OECs injected in } \\
\text { silicone tube }\end{array}$ & $\begin{array}{l}\text { improvement of CMAP } \\
\text { increased nerve fiber } \\
\text { regeneration and } \\
\text { thickness of myelination }\end{array}$ & $\begin{array}{l}\text { no limits or side } \\
\text { effects reported }\end{array}$ & $\begin{array}{l}\text { Cheng et al., } \\
2003 \text { [17] }\end{array}$ \\
\hline $\begin{array}{l}\text { Sciatic nerve } \\
\text { transaction (rat) }\end{array}$ & OB OECs & $\begin{array}{l}\text { OEC injection in } \\
\text { lesion side }\end{array}$ & $\begin{array}{l}\text { enhancement of axonal } \\
\text { regeneration reduction of } \\
\text { motoneuron apoptosis }\end{array}$ & $\begin{array}{l}\text { no significant } \\
\text { difference in } \\
\text { neuronal survival in } \\
\text { experimental and } \\
\text { control groups }\end{array}$ & $\begin{array}{l}\text { Wang et al., } \\
2005[18]\end{array}$ \\
\hline $\begin{array}{l}\text { Sciatic nerve } \\
\text { transaction (rat) }\end{array}$ & $\begin{array}{l}\text { olfactory mucosa } \\
\text { transplantation }\end{array}$ & $\begin{array}{l}\text { olfactory mucosa } \\
\text { transplantation }\end{array}$ & SFI increased & $\begin{array}{l}\text { Control group only } \\
\text { nontransected } \\
\text { animals }\end{array}$ & $\begin{array}{l}\text { Delaviz et al.. } \\
2008 \text { [19] }\end{array}$ \\
\hline $\begin{array}{l}\text { Sciatic nerve } \\
\text { transaction and } \\
\text { microsurgical repair } \\
\text { by suture (rat) }\end{array}$ & $\begin{array}{l}\text { GFP-OECs } \\
\text { purified/PKH } \\
\text { labeled } \\
30,000 \text { cells/ } \mu \mathrm{L} \\
\text { and } 10 \mu \mathrm{L} \text { used }\end{array}$ & $\begin{array}{l}\text { OECs injection } \\
\text { proximal and distal } \\
\text { to lesion }\end{array}$ & $\begin{array}{l}\text { Axonal regeneration and } \\
\text { remyelination newly } \\
\text { formed nodes of Ranvier } \\
\text { functional improvement }\end{array}$ & $\begin{array}{l}\text { Observation interval } \\
\text { limited to } 3 \text { weeks }\end{array}$ & $\begin{array}{l}\text { Radtke et al., } \\
2009[20]\end{array}$ \\
\hline $\begin{array}{l}\text { Sciatic nerve lesion } \\
12-15 \mathrm{~mm} \text { gap and } \\
\text { tube implantation } \\
\text { (rat) }\end{array}$ & $\begin{array}{l}\text { Purified } \\
\text { PKH-labelled } \\
\text { OB OECs } \\
120,000 \text { cells/tube }\end{array}$ & $\begin{array}{l}\text { Silicone tubel } \\
\text { prefilled with } \\
\text { OECs in } \\
\text { laminin gel }\end{array}$ & $\begin{array}{l}\text { Enhancement axonal } \\
\text { regeneration increased } \\
\text { CMAP functional } \\
\text { improvement }\end{array}$ & $\begin{array}{l}\text { Regeneration } \\
\text { limit at } 15 \mathrm{~mm} \\
\text { Regeneration in } \\
50 \% \text { of animals }\end{array}$ & $\begin{array}{l}\text { Verdu et al., } \\
1999[21]\end{array}$ \\
\hline $\begin{array}{l}\text { Sciatic nerve lesion } \\
10 \mathrm{~mm} \text { PLGA } \\
\text { conduit } \\
\text { implantation (rat) }\end{array}$ & $\begin{array}{l}\text { CM-Dil labeled } \\
\text { OECs in } \\
1 \times 10,000 \mu \mathrm{L} \text { and } \\
50 \mu \mathrm{L} \text { used }\end{array}$ & $\begin{array}{l}\text { PLGA filled with } \\
\text { OECs } \\
\text { OECs in EMC }\end{array}$ & $\begin{array}{l}\text { Nerve fiber regenation } \\
\text { motor function } \\
\text { recovery NCV and } \\
\text { CMAP recovery }\end{array}$ & $\begin{array}{l}\text { No recovery SFI } \\
\text { after } 12 \text { weeks }\end{array}$ & $\begin{array}{l}\text { Li et al., } 2010 \\
{[22]}\end{array}$ \\
\hline $\begin{array}{l}\text { Sciatic nerve lesion } \\
20 \mathrm{~mm} \text { and PLGA } \\
\text { conduit } \\
\text { implantation (rat) }\end{array}$ & $\begin{array}{l}\text { Purified OECs } \\
\text { Hoechst-labelled } \\
3 \times 100,000 \mu \mathrm{L} \\
\text { and } 20 \mu \mathrm{L} \text { used }\end{array}$ & $\begin{array}{l}\text { PLGA filled with } \\
\text { OECs } \\
\text { OECs in EMC }\end{array}$ & $\begin{array}{l}\text { Enhancement axonal } \\
\text { regeneration increased } \\
\text { myelinated fibers } \\
\text { recovery sensory and } \\
\text { motor function }\end{array}$ & $\begin{array}{l}20 \% \text { of rats showed } \\
\text { autophagia and } \\
\text { heel ulcers }\end{array}$ & $\begin{array}{l}\text { You et al., } \\
2010[23]\end{array}$ \\
\hline $\begin{array}{l}\text { Sciatic nerve lesion } \\
\text { and } 20 \mathrm{~mm} \\
\text { resection, no } \\
\text { surgical repair (rat) }\end{array}$ & $\begin{array}{l}\text { Cultured OECs } \\
\text { from olfactory } \\
\text { bulb GFP-labelled } \\
\text { cells, purity was } \\
\text { determined by } \\
\text { p75NGFR }\end{array}$ & $\begin{array}{l}\text { Cell suspension } \\
\text { was laid into } \\
\text { transaction site } \\
\text { immediately } \\
\text { after resection }\end{array}$ & $\begin{array}{l}\text { Muscle strength and } \\
\text { morphometric axon } \\
\text { counting with complete } \\
\text { restoration, increase of } \\
\text { neurotrophic factors }\end{array}$ & $\begin{array}{l}\text { OECs did not } \\
\text { directly on axonal } \\
\text { regrowth, but seem } \\
\text { to create favorable } \\
\text { microenviroment }\end{array}$ & $\begin{array}{l}\text { Guerout et al., } \\
\text { 2011a [24] }\end{array}$ \\
\hline
\end{tabular}


Table 1. Cont.

\begin{tabular}{|c|c|c|c|c|c|}
\hline Nerve lesion model & OEC condition & OEC application & Outcome & Limits & Reference \\
\hline $\begin{array}{l}\text { Sciatic nerve lesion } \\
15 \mathrm{~mm} \text { and biogenic } \\
\text { conduit implantation } \\
\text { (rat) }\end{array}$ & $\begin{array}{l}\text { Purified neonatal } \\
\text { OECs or purified } \\
\text { neonatal SCs }\end{array}$ & $\begin{array}{l}\text { Conduits filled with } \\
\text { OECs or SCs }\end{array}$ & $\begin{array}{l}\text { Improvement in motor } \\
\text { function }\end{array}$ & $\begin{array}{l}\text { Recovery better } \\
\text { after SCs compared } \\
\text { to OECs with } \\
\text { conduit implantation } \\
\text { nerve transplant } \\
\text { best results }\end{array}$ & $\begin{array}{l}\text { Penna et al., } \\
2012[25]\end{array}$ \\
\hline $\begin{array}{l}\text { Facial nerve lesion } \\
\text { (rats) } 5 \mathrm{~mm} \\
\text { interstump distance } \\
\text { silicone tube }\end{array}$ & $\begin{array}{l}\text { OB OECs } \\
\text { deplated of } \\
\text { fibroblasts } \\
200,000 \text { OECs }\end{array}$ & $\begin{array}{l}\text { Collagen gel } \\
\text { containing OECs in } \\
\text { silicone tube }\end{array}$ & $\begin{array}{l}\text { Increased motoneurons } \\
10 \text { fold increase in } \\
\text { motoneurons increased } \\
\text { sproutuing and } \\
\text { pathfinding }\end{array}$ & $\begin{array}{l}\text { No functional } \\
\text { alterations }\end{array}$ & $\begin{array}{l}\text { Guntinas- } \\
\text { Lichius et al., } \\
2001[26]\end{array}$ \\
\hline $\begin{array}{l}\text { Facial nerve lesion } \\
\text { (rat) end-to end } \\
\text { anastomosis }\end{array}$ & $\begin{array}{l}\text { OM freshly } \\
\text { prepared detection } \\
\text { by y-chromsome }\end{array}$ & $\begin{array}{l}\text { OM laid over } \\
\text { sutured epineurium }\end{array}$ & $\begin{array}{l}\text { Reduction of collateral } \\
\text { branching promatio of } \\
\text { functional recovery } \\
\text { sustained expression } \\
\text { trophic factors }\end{array}$ & $\begin{array}{l}\text { No improvement of } \\
\text { accuracy of } \\
\text { reinnervation }\end{array}$ & $\begin{array}{l}\text { Guntinas- } \\
\text { Lichius et al., } \\
2002[27]\end{array}$ \\
\hline $\begin{array}{l}\text { Facial nerve lesion } \\
\text { (rat) }\end{array}$ & $\begin{array}{l}\text { OB OECs } \\
\text { and OM } \\
\text { transplantation }\end{array}$ & $\begin{array}{l}\text { OM pieces were } \\
\text { applied OEC } \\
\text { suspension injected }\end{array}$ & $\begin{array}{l}\text { Moderate nerve } \\
\text { regeneration }\end{array}$ & $\begin{array}{l}\text { Only OM yielded in } \\
\text { major improvement }\end{array}$ & $\begin{array}{l}\text { Angelov et al., } \\
2005[28]\end{array}$ \\
\hline $\begin{array}{l}\text { Fiacial nerve lesion } \\
\text { (rat) and immediate } \\
\text { repair by suture }\end{array}$ & $\begin{array}{l}\text { Mixed OECs and } \\
\text { S-type OECs }\end{array}$ & $\begin{array}{l}\text { Bolus of cultured } \\
\text { cells was applied to } \\
\text { the cut ends before } \\
\text { suture }\end{array}$ & $\begin{array}{l}\text { Increased rate of eye } \\
\text { closure recovery }\end{array}$ & $\begin{array}{l}\text { Disorganization of } \\
\text { the facial nucleus } \\
\text { and aberrant nerve } \\
\text { branching } \\
\text { unchanged }\end{array}$ & $\begin{array}{l}\text { Choi and } \\
\text { Raisman, } \\
2005 \text { [29] }\end{array}$ \\
\hline $\begin{array}{l}\text { recurrent laryngeal } \\
\text { nerve section/ } \\
\text { anastomosis (rat) }\end{array}$ & $\begin{array}{l}\text { OECs from } \\
\text { mucosa } \\
\text { (OM-OECs), or } \\
\text { olfactory bulb } \\
\text { (OB-OECs) or } \\
\text { co-transplantation } \\
\text { of both }\end{array}$ & $\begin{array}{l}\text { Cells were } \\
\text { laid over } \\
\text { section/anastomosis } \\
\text { site immediately at } \\
\text { the time of surgery } \\
(6 \times 10,000 \text { cells })\end{array}$ & $\begin{array}{l}\text { Co-transplantation of } \\
\text { OM-OECs and } \\
\text { OB-OECs supported } \\
\text { major functional } \\
\text { recovery with reduction } \\
\text { of synkinesis }\end{array}$ & $\begin{array}{l}\text { OM-OECs or } \\
\text { OB-OECs displayed } \\
\text { opposite abilities to } \\
\text { improve functional } \\
\text { recovery }\end{array}$ & $\begin{array}{l}\text { Guerout et al., } \\
\text { 2011b [30] }\end{array}$ \\
\hline $\begin{array}{l}\text { Vagus nerve } \\
\text { transaction and } \\
\text { immediate repair by } \\
\text { suture }\end{array}$ & $\begin{array}{l}\text { Cultivated } \\
\text { olfactory bulb or } \\
\text { cultivated } \\
\text { olfactory mucosa } \\
\text { of non-cultivated } \\
\text { olfact. mucosa }\end{array}$ & & $\begin{array}{l}\text { best vocal fold angular } \\
\text { movement with } \\
\text { cultivated olfactory } \\
\text { mucosa in all cell groups } \\
\text { less synkinesis }\end{array}$ & & $\begin{array}{l}\text { de Corgnol } \\
\text { et al., } 2011 \\
{[31]}\end{array}$ \\
\hline $\begin{array}{l}\text { Complete vagus } \\
\text { nerve lesion and } \\
\text { anastomosis in rat }\end{array}$ & $\begin{array}{l}\text { GPF OM and } \\
\text { OB OECs } \\
5 \times 1,000,000 \\
\text { cells/animal }\end{array}$ & $\begin{array}{l}\text { OB or OM OECs } \\
\text { in matrigel per } \\
\text { micropipette in } \\
\text { anatomosis side }\end{array}$ & $\begin{array}{l}\text { Improvement of } \\
\text { reinnervation (EMG) } \\
\text { increased myelinated } \\
\text { fibers functional } \\
\text { improvement }\end{array}$ & $\begin{array}{l}\text { OM OECs improves } \\
\text { muscular activity } \\
\text { but no increases in } \\
\text { number of } \\
\text { myelinated fibers }\end{array}$ & $\begin{array}{l}\text { Pavoit et al., } \\
2011[32]\end{array}$ \\
\hline
\end{tabular}


Table 1. Cont.

\begin{tabular}{|c|c|c|c|c|c|}
\hline Nerve lesion model & OEC condition & OEC application & Outcome & Limits & Reference \\
\hline $\begin{array}{l}\text { Transection of dorsal } \\
\text { roots L3-L6 in rats }\end{array}$ & $\begin{array}{l}\text { OECs from } \\
\text { olfactory nerve } \\
\text { and glomerular } \\
\text { layer, } \\
\text { immunopurified } \\
\text { marked with } \\
\text { PKH28 }\end{array}$ & $\begin{array}{l}\text { Impantation into } \\
\text { DREZ }\end{array}$ & $\begin{array}{l}\text { promotion of central } \\
\text { regeneration and } \\
\text { functional } \\
\text { reconnection of } \\
\text { regenerating sensory } \\
\text { afferents, reflex } \\
\text { recovery }\end{array}$ & $\begin{array}{l}\text { immunoreactive } \\
\text { fibers entering DH } \\
\text { with lower density } \\
\text { than contalateral } \\
\text { side }\end{array}$ & $\begin{array}{l}\text { Navarro et al., } \\
1999[33]\end{array}$ \\
\hline $\begin{array}{l}\text { Dorsal root } \\
\text { rhizotomy at } \\
\text { C3-T3 in rats }\end{array}$ & $\begin{array}{l}\text { purified } \\
\text { OB-OECs }\end{array}$ & $\begin{array}{l}\text { direct OEC } \\
\text { transplantation } \\
\text { dorsal horn OEC } \\
\text { transplants or into } \\
\text { the DREZ }\end{array}$ & $\begin{array}{l}\text { axons regenerated at } \\
\text { the rhizotomy site }\end{array}$ & $\begin{array}{l}\text { no regeneration } \\
\text { across DREZ } \\
\text { no regeneration into } \\
\text { dorsal horn }\end{array}$ & $\begin{array}{l}\text { Gomez et al., } \\
2003[34]\end{array}$ \\
\hline $\begin{array}{l}\text { Doral root entry } \\
\text { zone/dorsal horn } \\
\text { rhizotomy in rats }\end{array}$ & $\begin{array}{l}\text { purified by } \\
\text { p75NGFR OECs } \\
\text { identification by } \\
\beta \text {-gal } \\
30,000-200,000 \\
\text { cells }\end{array}$ & $\begin{array}{l}\text { injection of OEC } \\
\text { suspension at } \\
\text { DREZ/DH }\end{array}$ & $\begin{array}{l}\text { no advantage in } \\
\text { promoting ingrowth of } \\
\text { afferent fibers in } \\
\text { DREZ }\end{array}$ & $\begin{array}{l}\text { no evidence of } \\
\text { functional recovery } \\
\text { of afferent fibers, } \\
\text { minimal ingrowth } \\
\text { of afferent fibers } \\
\text { in SpC }\end{array}$ & $\begin{array}{l}\text { Riddell et al., } \\
2004 \text { [35] }\end{array}$ \\
\hline $\begin{array}{l}\text { Dorsal root } \\
\text { transection at L4 } \\
\text { in rats }\end{array}$ & $\begin{array}{l}\text { endogenous } \\
\text { matrix containing } \\
\text { GFP-OECs }\end{array}$ & $\begin{array}{l}\text { direct application } \\
\text { to surfaces of } \\
\text { rootlet and } \mathrm{SpC} \\
\text { combined with } \\
\text { fibrin glue }\end{array}$ & $\begin{array}{l}\text { regenerated dorsal root } \\
\text { axons crossed repaired } \\
\text { DREZ }\end{array}$ & $\begin{array}{l}\text { transplanted cells } \\
\text { did not enter the } \\
\text { spinal cord itself }\end{array}$ & $\begin{array}{l}\text { Li et al., } 2004 \\
\text { [36] }\end{array}$ \\
\hline $\begin{array}{l}\text { Cervical or lumbar } \\
\text { dorsal root lesion } \\
\text { in rats }\end{array}$ & $\begin{array}{l}\text { GFP-OECs from } \\
\text { lamina propria }\end{array}$ & $\begin{array}{l}\text { OECs transplanted } \\
\text { into DRG, intact or } \\
\text { injured dorsal roots } \\
\text { or the dorsal } \\
\text { columns via DREZ }\end{array}$ & $\begin{array}{l}\text { OECs migration into } \\
\text { the } \mathrm{DRG} / \text { dorsal root }\end{array}$ & $\begin{array}{l}\text { OECs migrated } \\
\text { within the PNS but } \\
\text { did not cross the } \\
\text { DREZ no primary } \\
\text { afferent } \\
\text { regeneration }\end{array}$ & $\begin{array}{l}\text { Ramer et al., } \\
2004 \text { [37] }\end{array}$ \\
\hline $\begin{array}{l}\text { Dorsal roots } \\
\text { transection } \\
\text { C5-T2 acute and } \\
\text { chronic lesion (rats) }\end{array}$ & $\begin{array}{l}\text { GFP-OECs from } \\
\text { OB }\end{array}$ & $\begin{array}{l}\text { OECs injection in } \\
\text { roots } \mathrm{C} 4-\mathrm{T} 1\end{array}$ & $\begin{array}{l}\text { restoration fore-paw } \\
\text { function recovery } \\
\text { sensory input axonal } \\
\text { regeneration }\end{array}$ & $\begin{array}{l}\text { none of chronically } \\
\text { rhizotomized rats } \\
\text { showed } \\
\text { electrophysiological } \\
\text { responses }\end{array}$ & $\begin{array}{l}\text { Ibrahim et al., } \\
2009[38]\end{array}$ \\
\hline $\begin{array}{l}\text { Dorsal root injury at } \\
\mathrm{C} 7 \text { and } \mathrm{C} 8 \text { in rats }\end{array}$ & $\begin{array}{l}\text { GFP-cultures } \\
\text { enriched for OECs } \\
6 \times 10,000 \text { cells }\end{array}$ & $\begin{array}{l}\text { stereotactic } \\
\text { injection into } \\
\text { dorsal horn }\end{array}$ & $\begin{array}{l}\text { attenuation of } \\
\text { neuropathic pain }\end{array}$ & $\begin{array}{l}\text { no improvement } \\
\text { sensory function } \\
\text { increasement of } \\
\text { selfmutilation no } \\
\text { functional } \\
\text { improvement }\end{array}$ & $\begin{array}{l}\text { Wu et al., } \\
2010 \text { [39] }\end{array}$ \\
\hline $\begin{array}{l}\text { Avulsion of ventral } \\
\text { root at S1 and } \\
\text { reimplantation (rat) }\end{array}$ & $\begin{array}{l}\text { GFP-OECs and } \\
\text { fibroblasts } 1: 1\end{array}$ & $\begin{array}{l}\text { OECs transplanted } \\
\text { at } \mathrm{SpC} \text { interface } \\
\text { OECs matrix cut } \\
\text { into pieces }\end{array}$ & $\begin{array}{l}\text { increase of fibers } \\
\text { crossing lesion side } \\
\text { migration of OECs }\end{array}$ & $\begin{array}{l}20 \% \text { of fibers enter } \\
\text { roots without OEC } \\
\text { transplantation }\end{array}$ & $\begin{array}{l}\text { Li et al., } 2007 \\
{[17]}\end{array}$ \\
\hline
\end{tabular}


Most experimental studies using OECs as a cell therapy have focused on spinal cord injury. A recent Pubmed search indicates that while there have been over 560 publications related to olfactory ensheathing cells the large majority of these studies are related to spinal cord injury. Only 27 OEC publications are related to transplantation of OECs in peripheral nerve injury models (See Table 1). Several lesion models of peripheral nerve injury have been used to study the potential of OEC transplantation to enhance nerve repair. OECs have been transplanted into sciatic nerve injury models including nerve crush [16] and nerve transection [18-20]. OECs have also been seeded on conduit implantations for nerve defect repair [21,23,36,40]. Another peripheral nerve lesion model where OECs have been transplanted is the injured facial nerve [12,26-29]. This later model has the advantage that motor recovery can be easily assayed by vibrissae movement. OECs have also been used in dorsal root injury models where the potential of sensory neurons to regenerate into the spinal cord has been studied [35,38,39]. One study used OECs for vagus nerve repair [32] and one study for ventral root repair [3]. In contrast to spinal cord repair by OEC cell transplantation, the peripheral nerve injury model studies have focused exclusively on rodents and have not as yet been transferred to larger animal models (e.g., rabbit, sheep, monkey). Moreover, while several clinical studies for spinal cord injury have been carried out, OEC clinical studies for peripheral nerve repair have not yet been initiated. In the following sections we review results from these limited studies of OECs in peripheral nerve repair.

\section{OEC Transplantation into Sciatic Nerve Supports Axonal Regeneration and Remyelination}

OECs prepared as cell suspension from the olfactory bulb [16,18,20] or the olfactory mucosa [19] have been transplanted directly into injured nerve. Dombrowski et al. [16] transplanted OECs into injured peripheral nerve (crush injury) to determine if the OECs could survive and myelinate the regenerated axons and determined additionally sodium channel expression and formation of nodes of Ranvier. Structural analysis of the regenerated axons in terms of nodal sodium channels was analyzed and results indicated that transplanted OECs integrate into peripheral nerve transected by crush injury, form peripheral-like myelin on regenerated peripheral nerve fibers and that the OECs are able to signal the regenerated axons to reconstruct nodes of Ranvier (Figure 1A,B) with proper sodium channel (Nav1.6) organization (Figure 1A, inset).

In a subsequent study, combined microsurgical suture repair of the completely transected sciatic nerve with OEC transplantation was performed, and structural and functional outcomes were assessed [20]. The results of this study indicated that OEC transplantation used as an adjunct approach to microsuture repair results in improved structural (Figure 2A-C) outcome. Quantitatively measurements of myelinated axons in the OEC implanted nerves demonstrated an increase in myelinated axons after transplantation of OECs. Moreover, there was functional improvement greater than in surgical repair with vehicle injection as assayed with foot print analysis. The modest improvement in function at early (1-2 weeks) post-repair time points may be from facilitation of regeneration to more proximal musculature.

What might account for this improvement in nerve repair with combined OEC transplantation? While endogenous Schwann cells are intrinsic facilitators of peripheral nerve repair, they require several days to mobilize after nerve injury as they retract from injured or degenerating axons and 
subsequently express the low affinity p75 nerve growth factor receptor (p75NGFR), nerve growth factor (NGF) and other molecules which are conducive to axonal regeneration. Cultured OECs are "primed" and express these factors at the time of transplantation. After nerve transection the cut axons die-back for several millimeters over the course of several days. The axons then sprout and regenerate axons that attempt to navigate the lesion domain and reinnervate peripheral targets. The transplanted OECs may provide immediate trophic support which could account for the improved regeneration. Moreover, if there is reduced axonal die-back and earlier regeneration onset from the proximal nerve stump associated with OEC transplantation at the time of repair, the axons may be able to navigate the repair site before significant scar formation ensues. In a recent paper Guerout et al. [24] demonstrate significant enhancement of nerve regeneration after a severe sciatic nerve lesion and transplantation of OECs. They observed a significant increase in neurotrophic factors in the transplanted group arguing for a neurotrophic effect by the transplanted cells as a facilitator of nerve regeneration. OEC transplantation can also facilitate recurrent laryngeal nerve regeneration [30,31]. One study used SCs and OECs in a nerve conduit model and found that SCs were more effective in promoting axonal regeneration [25]. Navarro et al. [33] found that OECs promoted dorsal root regeneration, but Ramer et al. [37] found that they did not.

Figure 1. (A) Regenerated axons are myelinated by transplanted GFP-OECs. (B) Boxed image from (A) shows nodes of Ranvier (arrows) of the regenerated axons remyelinated by the transplanted OECs. Inset in B shows Na channel immunostaining at the newly formed node of Ranvier. Scale bar in A is $10 \mu \mathrm{m}$. Scale bar in B is $80 \mu \mathrm{m}$. (Modified with permission from Radtke et al. [20])

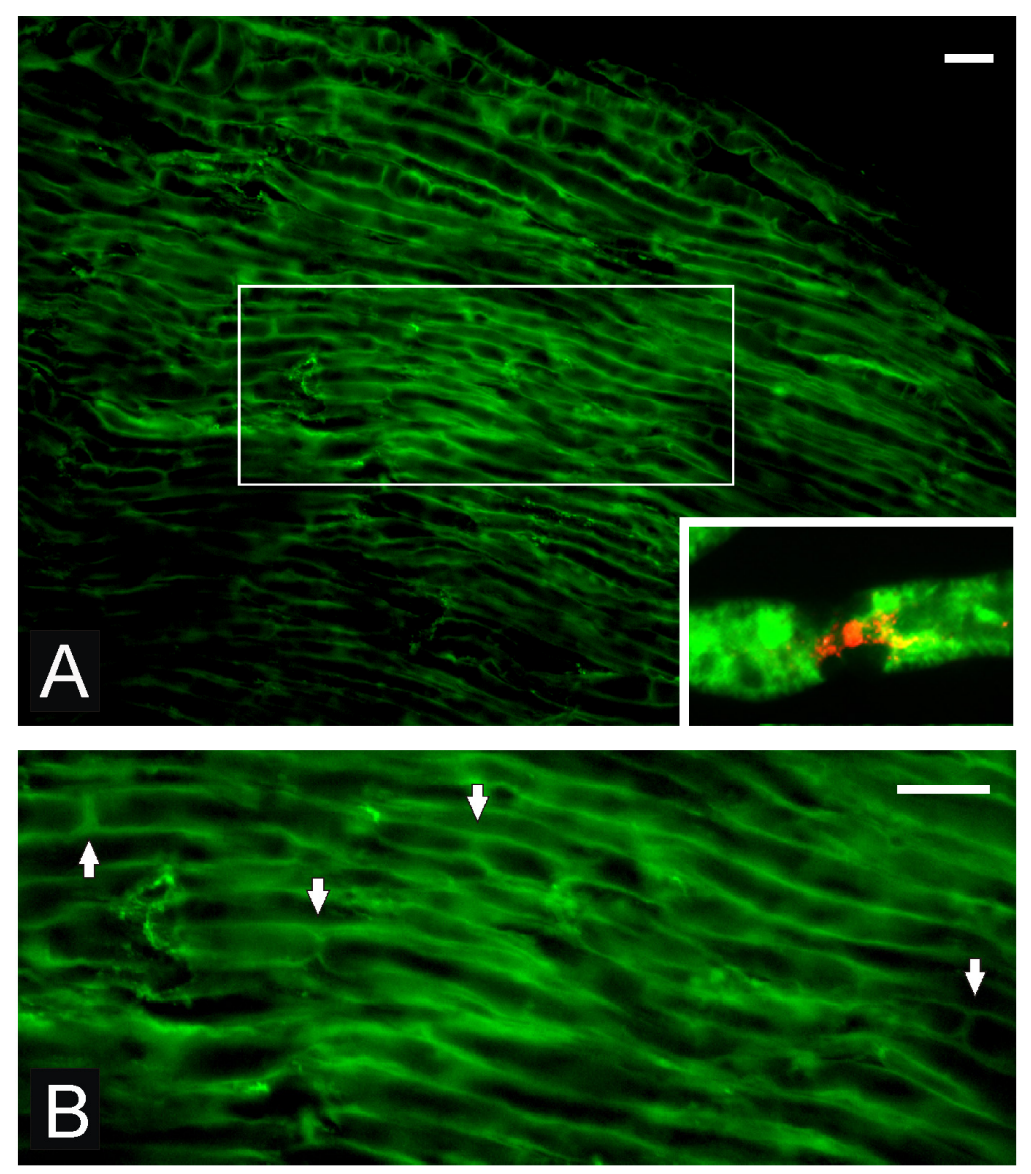


Figure 2. Coronal sections of repaired nerves by suture alone (A) and microsurgical repair combined with OEC transplantation (B) at three weeks post surgery. Increased numbers of myelinated axons after transplantation of OECs in the proximal segment can be observed. (C) and (D): Histological and electrophysiological outcomes between sham control (suture alone) and transplant (suture combined with OEC transplantation) animals. The number of myelinated axons (C) and the conduction velocity (D) were increased 36 days after surgery. Data are presented as means \pm SE. Statistical evaluations were based on two-tailed $t$-test, $\chi^{2}$ test (Origin; criterion, * and $* * p<0.05$ ). Scale bar in $\mathrm{A}=20 \mu \mathrm{m}$. (Modified with permission from Radtke et al. [20])
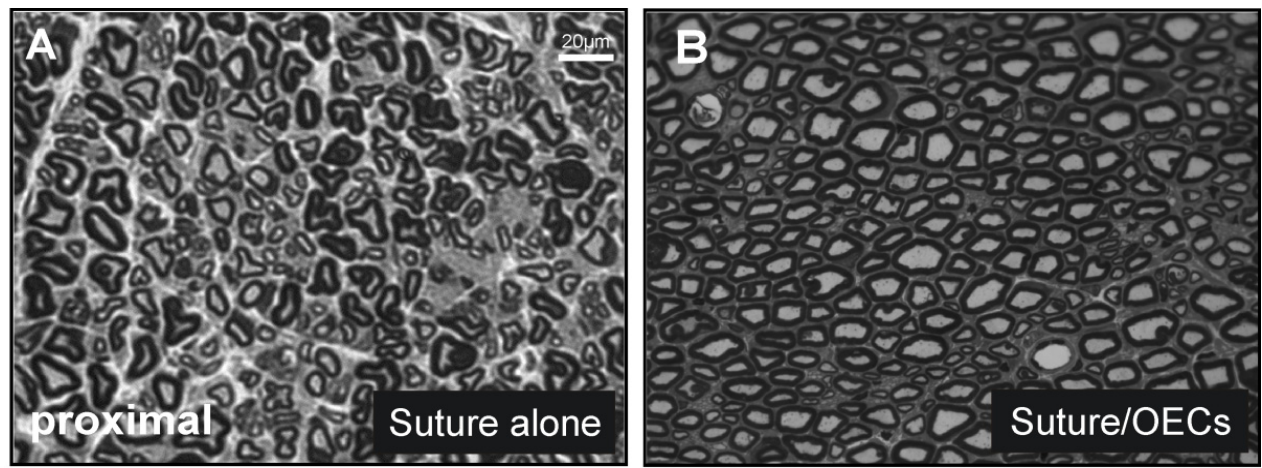

C

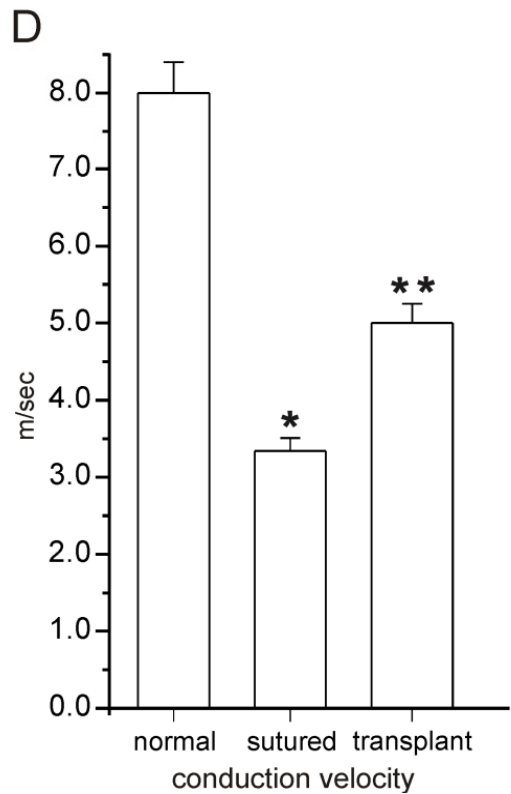

\section{Implantation of OEC-Seeded Scaffolds for Nerve Substance Defect Repair}

The clinical outcome in long distance nerve defects is particularly disappointing and the development of interventional approaches to improve functional recovery is continuing. A complicating factor is the trauma-associated loss of nerve tissue (substance defect) where autologous nerve grafts are required, but are limited in availability. A promising alternative to conventional autologous nerve grafting as described above is the utilization of artificial nerve grafts in the form of scaffolds or conduits [21-23,41]. While the functional outcome is often suboptimal, efforts are being made to overcome these restrictions. The addition of supportive cells to the nerve tube to optimize results is an extensively investigated modification to a single-lumen nerve tube. In the repair of small 
nerve defects with insertion of empty hollow nerve tubes, Schwann cells are also involved in the process of regeneration by endogenous migration. The addition of OECs might further enhance regeneration. OECs were evaluated regarding their properties after seeding into a variety of scaffolds. Tang et al. [40] evaluated the compatibility of a collagen-heparan sulfate (CHS) biological nerve tube filled with OECs. The scaffolds were co-cultured with OECs in vitro. The attachment and growth of OECs in CHS scaffolds were observed indicating that the scaffold is a possible cell carrier for the implantation of OECs in nerve tissue bioengineering. Moreover, purified olfactory mucosa-derived OECs were seeded onto a bioengineered hybrid scaffold consisting of various extracellular matrix (ECM) proteins and cultured. A stable porous 3-D network was formed, and OECs seeded on the scaffold maintained the expression of nerve growth factor, matrix metalloproteinase- 3 and matrix metalloproteinase-9 was studied in vitro [41]. In silk fiber scaffolds with different fiber diameters and seeded with OECs, characteristics of OECs were observed by analyzing cell morphological feature, distribution, and proliferation. OECs specific cell markers could be maintained and the migration including tracks, turning behavior, migration distances, migration speeds, and forward migration indices were calculated [42]. Additionally, the scaffold material itself has a noticeable effect on OEC growth and proliferation. In comparison of the copolymers PDLLA (poly-DL-lactide) and PLGL or poly[LA-co-(Glc-alt-Lys)], PLGL possesses better hydrophilicity and biocompatibility and provided a better cell growth for neonatal OECs [43].

A recent study evaluated the compatibility between the copolymer PLGA or poly (lactic-co-glycolic acid) and OECs in vitro, and the effect of a PLGA conduit filled with OECs and silicon-extracellular matrix gel on a $10 \mathrm{~mm}$-defect in the sciatic nerve in rat [22]. The nerve conduction velocity and the amplitude of compound muscle action potential were more improved in the PLGA-guided group than in the control silicon-guided group. The PLGA-OEC conduits also had a greater number of regenerated axons. However, there was no difference between the groups in the functional outcome measured by sciatic functional index at 12 weeks after surgery, which the authors attribute to the severity of the nerve injury model [22].

In another study OECs suspended in laminin gel and seeded in a silicone tube were used to bridge a $15 \mathrm{~mm}$ gap in rat sciatic nerve [21]. The OEC seeded tubes were much more successful in promoting nerve regeneration than were the tubes alone. The use of nerve conduit implantation for the treatment of nerve substance defects is the subject of intensive ongoing research. Establishment of the proper combination of conduit material and cell seeding will be important to advance success for peripheral nerve tissue engineering.

\subsection{OECs for Facial Nerve Repair}

Comparable to the sciatic nerve lesion model, OECs prepared from the olfactory bulb and the olfactory mucosa were used in facial nerve lesions in rats. In these lesion models either the facial nerve was directly anastomosed or a repair with a $5 \mathrm{~mm}$ interstump distance combined with a silicone tube was performed [26,27]. In both studies increased sprouting and pathfinding could be observed, but no improvement of accuracy of reinnervation or functional alterations could be shown. OEC transplantation into transected facial nerve enhances axonal sprouting $[12,26]$, promotes recovery of vibrissae motor performance [27] and increases the rate of eye closure [37]. OECs were tested in 
several studies for facial nerve repair. Moreover, Angelov et al. [28] demonstrated moderate nerve regeneration, but only olfactory mucosa resulted in functional improvement. Thus, reports of achievement of functional repair in the sciatic nerve model system with OEC transplantation have shown more success than in facial nerve repair. A recent study carried out complete rat vagus nerve lesion followed by surgical anastomosis combined olfactory bulb (OB) or olfactory mucosa (OM) OECs transplantation. Here, improvement of reinnervation was observed by EMG testing, and demonstration of increased numbers of regenerated myelinated fibers and functional improvement [32].

\subsection{OECs in Dorsal Root Injury}

Axon growth-promoting properties of OECs were determined by several studies using dorsal and ventral root lesion models in the adult rat. The lesion models include dorsal and ventral root avulsion followed by root reimplantation and as well acute and chronic transection models. However, whereas early in vivo studies reported facilitated entry of peripheral sensory dorsal root ganglionic axons by transplantation of OECs [2,33] other studies could not support these observations [35,37]. Additionally, Li et al. [44] reported beneficial effects of transplanted OECs to the reanastomosed ventral S1 root with increased fibers crossing the lesion side when OECs combined with fibroblasts were transplanted at the spinal cord-root interface. Ibrahim et al. [38] reported on transplantation of OECs in a brachial plexus injury model. Here, OECs increased regeneration at both the anatomical and functional level.

\section{Concluding Remarks}

Peripheral nerve injury constitutes a critical and common clinical problem. While simple nerve repairs can often lead to considerable functional improvement, clinical outcomes are not fully optimal. Experimental studies performed in rodents show that transplantation of OECs into injured nerve or implantation of OEC-seeded conduits leads to an enhancement in axonal regeneration and improved functional outcome under some experimental conditions. Axonal die-back of the proximal nerve stump is reduced in the OEC transplanted nerves suggesting that the OECs provided early trophic support leading to earlier onset of regeneration. This could be critical for allowing the regenerating axons to navigate across the injury site before impeding scar tissue develops. However, OECs share many properties with Schwann cells such as their production of neurotrophic factors and extracellular matrix molecules as well as their ability to form peripheral myelin. There are few direct comparisons between the nerve repair potential of OECs and Schwann cells. Moreover, OECs could in principle promote Schwann cell proliferation, thus having an indirect effect on nerve repair. Transplanted identified eGFP-expressing OECs integrate into the nerve injury site and remyelinate the regenerated axons, suggesting direct participation of OECs in the repair process. Yet, transplantation of Schwann cells shows similar integration emphasizing the need for studies to compare the relative repair potential of OECs and Schwann cells. Future work with biosynthetic constructs seeded with cells such as OECs will represent an important area of research for potentially establishing novel therapeutic approaches for nerve injury. Another issue with regard to comparing various studies using OECs for nerve repair, is that many of the studies use OECs prepared from different age animals (neonate $v s$. adult), from different sites of derivation (e.g., nasal muscosa vs. olfactory bulb) and methods of cell purification. In 
spite of these differences, to date the enhancement of axonal regeneration and remyelination following OEC transplantation into the injured peripheral nervous appears to be fact. Yet, many questions remain to be addressed as to the best source of OECs and the optimal culture conditions to be used prior to transplantation.

\section{Acknowledgements}

Previous and current studies by CR reviewed in the present article have been supported by the German Research Foundation (Ra 1901/1-1) and the Hochschulinterne Leistungsföderung (HiLF) of the Hannover Medical School.

\section{References}

1. Furey, M.; Midha, R.; Xu, Q.B.; Belkas, J.; Gordon, T. Prolonged target deprivation reduces the capacity of injured motoneurons to regenerate. Neurosurgery 2007, 60, 723-733.

2. Ramón-Cueto, A.; Nieto-Sampedro, M. Regeneration into the spinal cord of transected dorsal root axons is promoted by ensheathing glia transplants. Exp. Neurol. 1994, 127, 232-244.

3. Li, Y.; Field, P.M.; Raisman, G. Repair of adult rat corticospinal tract by transplants of olfactory ensheathing cells. Science 1997, 297, 2000-2002.

4. Franklin, R.J.; Gilson, J.M.; Franceschini, I.A.; Barnett, S.C. Schwann cell-like myelination following transplantation of an olfactory bulb-ensheathing cell line into areas of demyelination in the adult CNS. Glia 1996, 17, 217-224.

5. Imaizumi, T.; Lankford, K.L.; Waxman, S.G.; Greer, C.A.; Kocsis, J.D. Transplanted olfactory ensheathing cells remyelinate and enhance axonal conduction in the demyelinated dorsal columns of the rat spinal cord. J. Neurosci. 1998, 18, 6176-6185.

6. Kato, T.; Honmou, O.; Uede, T.; Hashi, K.; Kocsis, J.D. Transplantation of human olfactory ensheathing cells elicits remyelination of demyelinated rat spinal cord. Glia 2000, 39, 209-218.

7. Sasaki, M.; Black, J.A.; Lankford, K.L.; Tokuno, H.A.; Waxman, S.G.; Kocsis, J.D. Molecular reconstruction of nodes of Ranvier after remyelination by transplanted olfactory ensheathing cells in the demyelinated spinal cord. J. Neurosci. 2006, 28, 1803-1812.

8. Feron, F.; Perry, C.; Cochrane, J.; Licina, P.; Nowitzke, A.; Urquhart, S.; Geraghty, T.; Mackay-Sim, A. Autologous olfactory ensheathing cell transplantation in human spinal cord injury. Brain 2005, 135, 3851-3860.

9. Mackay-Sim, A.; Féron, F.; Cochrane, J.; Bassingthwaighte, L.; Bayliss, C.; Davies, W.; Fronek, P.; Gray, C.; Kerr, G.; Licina, P.; et al. Autologous olfactory ensheathing cell transplantation in human paraplegia: A 3-year clinical trial. Brain 2000, 132, 2376-2386.

10. Huang, H.; Chen, L.; Wang, H.; Xiu, B.; Li, B.; Wang, R.; Zhang, J.; Zhang, F.; Gu, Z.; Li, Y.; et al. Influence of patients' age on functional recovery after transplantation of olfactory ensheathing cells into injured spinal cord injury. Chin. Med. J. 2003, 116, 1488-1491.

11. Lima, C.; Pratas-Vital, J.; Escada, P.; Hasse-Ferreira, A.; Capucho, C.; Peduzzi, J.D. Olfactory mucosa autografts in human spinal cord injury: A pilot clinical study. J. Spinal Cord Med. 2006, 38, 191-206. 
12. Deumens, R.; Koopmans, G.C.; Lemmens, M.; Möllers, S.; Honig, W.M.; Steinbusch, H.W.; Brook, G.; Joosten, E.A. Neurite outgrowth promoting effects of enriched and mixed OEC/ONF cultures. Neurosci. Lett. 2006, 417, 20-26.

13. Au, E.; Richter, M.W.; Vincent, A.J.; Tetzlaff, W.; Aebersold, R.; Sage, E.H.; Roskams, A.J. SPARC from olfactory ensheathing cells stimulates Schwann cells to promote neurite outgrowth and enhances spinal cord repair. J. Neurosci. 2007, 29, 7208-7236.

14. Cao, L.; Zhu, Y.L.; Su, Z.; Lv, B.; Huang, Z.; Mu, L.; He, C. Olfactory ensheathing cells promote migration of Schwann cells by secreted nerve growth factor. Glia 2007, 55, 897-904.

15. Sasaki, M.; Lankford, K.L.; Zemedkun, M.; Kocsis, J.D. Identified olfactory ensheathing cells transplanted into the transected dorsal funiculus bridge the lesion and form myelin. J. Neurosci. 2004, 26, 8485-8493.

16. Dombrowski, M.A.; Sasaki, M.; Lankford, K.L.; Kocsis, J.D.; Radtke, C. Myelination and nodal formation of regenerated peripheral nerve fibers following transplantation of acutely prepared olfactory ensheathing cells. Brain Res. 2006, 1127, 1-8.

17. Cheng, S.Y.; Ruan, H.Z.; Wu, X.G. Olfactory ensheathing cells enhance functional recovery of injured sciatic nerve. Zhongguo Xiu Fu Chong Jian Wai Ke Za Zhi 2003, 17, 18-36.

18. Wang, C.; Shi, Z.; Wang, K. Effect of olfactory ensheathing cells transplantation on protecting spinal cord and neurons after peripheral nerve injury. Chin. J. Repar. Reconstr. Surg. 2005, 19, $875-878$.

19. Delaviz, H.; Joghataie, M.T.; Mehdizadeh, M.; Bakhtiyari, M.; Nobakht, M.; Khoei, S. Transplantation of olfactory mucosa improve functional recovery and axonal regeneration following sciatic nerve repair in rats. Iran. Biomed. J. 2008, 12, 197-202.

20. Radtke, C.; Aizer, A.A.; Agulian, S.K.; Lankford, K.L.; Vogt, P.M.; Kocsis, J.D. Transplantation of olfactory ensheathing cells enhances peripheral nerve regeneration after microsurgical nerve repair. Brain Res. 2009, 1274, 10-17.

21. Verdú, E.; Navarro, X.; Gudiño-Cabrera, G.; Rodríguez, F.J.; Ceballos, D.; Valero, A.; Nieto-Sampedro, M. Olfactory bulb ensheathing cells enhance peripheral nerve regeneration. Neuroreport 1999, 10, 1097-1101.

22. Li, B.C.; Jiao, S.S.; Xu, C.; You, H.; Chen, J.M. PLGA conduit seeded with olfactory ensheathing cells for bridging sciatic nerve defect of rats. J. Biomed. Mater. Res. A 2010, 94, 769-780.

23. You, H.; Wei, L.; Liu, Y.; Oudega, M.; Jiao, S.S.; Feng, S.N.; Chen, Y.; Chen, J.M.; Li, B.C. Olfactory ensheathing cells enhance Schwann cell-mediated anatomical and functional repair after sciatic nerve injury in adult rats. Exp. Neurol. 2011, 238, 158-167.

24. Guérout, N.; Duclos, C.; Drouot, L.; Abramovici, O.; Bon-Mardion, N.; Lacoume, Y.; Jean, L.; Boyer, O.; Marie, J.P. Transplantation of olfactory ensheathing cells promotes axonal regeneration and functional recovery of peripheral nerve lesion in rats. Muscle Nerve 2011, 34, 534-551.

25. Penna, V.; Stark, G.B.; Wewetzer, K.; Radtke, C.; Lang, E.M. Comparison of Schwann Cells and Olfactory Ensheathing Cells for Peripheral Nerve Gap Bridging. Cells Tissues Organs 2012, doi:10.1159/000308059.

26. Guntinas-Lichius, O.; Angelov, D.N.; Tomov, T.L.; Dramiga, J.; Neiss, W.F.; Wewetzer, K. Transplantation of olfactory ensheathing cells stimulates the collateral sprouting from axotomized adult rat facial motoneurons. Exp. Neurol. 2001, 172, 70-80. 
27. Guntinas-Lichius, O.; Wewetzer, K.; Tomov, T.L.; Azzolin, N.; Kazemi, S.; Streppel, M.; Neiss, W.F.; Angelov, D.N. Transplantation of olfactory mucosa minimizes axonal branching and promotes the recovery of vibrissae motor performance after facial nerve repair in rats. J. Neurosci. 2002, 22, 7121-7131.

28. Angelov, D.N.; Guntinas-Lichius, O.; Wewetzer, K.; Neiss, W.F.; Streppel, M. Axonal branching and recovery of coordinated muscle activity after transection of the facial nerve in adult rats. Adv. Anat. Embryol. Cell Biol. 2005, 180, 1-130.

29. Choi, D.; Raisman, G. Disorganization of the facial nucleus after nerve lesioning and regeneration in the rat: Effects of transplanting candidate reparative cells to the site of injury. Neurosurgery 2005, 56, 1093-1100.

30. Guérout, N.; Paviot, A.; Bon-Mardion, N.; Duclos, C.; Genty, D.; Jean, L.; Boyer, O.; Marie, J.P. Co-transplantation of olfactory ensheathing cells from mucosa and bulb origin enhances functional recovery after peripheral nerve lesion. PLoS One 2011, 6, e23516.

31. De Corgnol, A.C.; Guérout, N.; Duclos, C.; Vérin, E.; Marie, J.P. Olfactory ensheathing cells in a rat model of laryngeal reinnervation. Ann. Otol. Rhinol. Laryngol. 2011, 120, 273-280.

32. Paviot, A.; Guérout, N.; Bon-Mardion, N.; Duclos, C.; Jean, L.; Boyer, O.; Marie, J.P. Efficiency of laryngeal motor nerve repair is greater with bulbar than with mucosal olfactory ensheathing cells. Neurobiol. Dis. 2011, 43, 688-694.

33. Navarro, X.; Valero, A.; Gudiño, G.; Forés, J.; Rodríguez, F.J.; Verdú, E.; Pascual, R.; Cuadras, J.; Nieto-Sampedro, M. Ensheathing glia transplants promote dorsal root regeneration and spinal reflex restitution after multiple lumbar rhizotomy. Ann. Neurol. 1999, 45, 207-215.

34. Goméz, V.M.; Averill, S.; King, V.; Yang, Q.; Doncel Pérez, E.; Chacón, S.C.; Ward, R.; Nieto-Sampedro, M.; Priestley, J.; Taylor, J. Transplantation of olfactory ensheathing cells fails to promote significant axonal regeneration from dorsal roots into the rat cervical cord. J. Neurocytol. 2003, 32, 53-70.

35. Riddell, J.S.; Enriquez-Denton, M.; Toft, A.; Fairless, R.; Barnett, S.C. Olfactory ensheathing cell grafts have minimal influence on regeneration at the dorsal root entry zone following rhizotomy. Glia 2004, 47, 150-167.

36. Li, Y.; Carlstedt, T.; Berthold, C.H.; Raisman, G. Interaction of transplanted olfactory ensheathing cells and host astrocytic processes provides a bridge for axons to regenerate across the dorsal root entry zone. Exp. Neurol. 2004, 188, 390-398.

37. Ramer, L.M.; Richter, M.W.; Roskams, A.J.; Tetzlaff, W.; Ramer, M.S. Peripherally-derived olfactory ensheathing cells do not promote primary afferent regeneration following dorsal root injury. Glia 2004, 47, 189-206.

38. Ibrahim, A.G.; Kirkwood, P.A.; Raisman, G.; Li, Y. Restoration of hand function in a rat model of repair of brachial plexus injury. Brain 2009, 132, 1288-1296.

39. Wu, A.; Lauschke, J.L.; Gorrie, C.A.; Cameron, N.; Hayward, I.; Mackay-Sim, A.; Waite, P.M. Delayed olfactory ensheathing cell transplants reduce nociception after dorsal root injury. Exp. Neurol. 2011, 238, 134-157.

40. Tang, Z.P.; Liu, N.; Li, Z.W.; Xie, X.W.; Chen, Y.; Shi, Y.H.; Zeng, W.G.; Wang, S.X.; Chen, J.; Yang, J.; et al. In vitro evaluation of the compatibility of a novel collagen-heparan sulfate biological scaffold with olfactory ensheathing cells. Chin. Med. J. 2010, 140, 1389-1394. 
41. Qian, L.M.; Zhang, Z.J.; Gong, A.H.; Qin, R.J.; Sun, X.L.; Cao, X.D.; Liu, J.B.; Jiang, P.; Chen, Y.C. A novel biosynthetic hybrid scaffold seeded with olfactory ensheathing cells for treatment of spinal cord injuries. Chin. Med. J. (Engl.) 2009, 122, 2032-2042.

42. Shen, Y.; Qian, Y.; Zhang, H.; Zuo, B.; Lu, Z.; Fan, Z.; Zhang, P.; Zhang, F.; Zhou, C. Guidance of olfactory ensheathing cell growth and migration on electrospun silk fibroin scaffolds. Cell Transplant. 2010, 19, 147-157.

43. Wang, Y.; Wang, Y.; Yin, Y.; Li, S.; Yan, Q.; Wan, Z.; Han, Y. Interaction of olfactory ensheathing cells with nerve repairing scaffolds. J. Cent. South Univ. (Med. Sci.) 2009, 31, 382-387.

44. Li, Y.; Yamamoto, M.; Raisman, G.; Choi, D.; Carlstedt, T. An experimental model of ventral root repair showing the beneficial effect of transplanting olfactory ensheathing cells. Neurosurgery 2007, 60, 731-743.

(C) 2012 by the authors; licensee MDPI, Basel, Switzerland. This article is an open access article distributed under the terms and conditions of the Creative Commons Attribution license (http://creativecommons.org/licenses/by/3.0/). 